\title{
A grounded analysis of year 8 students' reflections on information literacy skills and techniques and an identification of students' information literacy attributes.
}

\author{
James E Herring \\ Lecturer in Teacher Librarianship \\ Charles Sturt University \\ Australia
}

This research, undertaken in a UK high school, focuses on the views of year 8 students who were asked to reflect on their use of information literacy skills when completing an English assignment. A grounded analysis approach was taken in analysing the diaries which students completed during their assignment. Findings reveal a number of categories which illustrate the students' views of and use of information literacy skills.

Information literacy; grounded analysis; student diary

\section{Introduction}

This study took place in a UK state comprehensive school and focused on a class of year 8 $\left(2^{\text {nd }}\right.$ year of high school $)$ students who were completing a discursive essay on a topical issue as part of their English syllabus. Students completed a structured diary during their research for and completion of their written assignment. A semi-structured interview with the class teacher was done after the students completed their assignment. This study is part of a larger study which will seek to follow these students into year 9 and conduct interviews with students about aspects of information literacy.

\section{Research questions}

The aims of the study were to analyse and interpret the diary reflections of year 8 students and to identify the information literacy attributes of this class of students. The following research questions were posed:

How would students reflect on brainstorming, mind mapping and question formulation? 
$>$ Would students be able to link aspects of the information literacy process they were undertaking?

$>$ What factors would influence students' confidence during the assignment process?

$>$ How aware would students be of their information environment?

What information literacy attributes would this group of students demonstrate?

\section{Literature Review}

There is now a vast range of literature on information literacy in the school, higher education and workplace sector but there is no agreement as to one definition of information literacy or whether information literacy should be viewed as a concept, an ideal to be reached, a practice, a set of skills, set of competencies or a set of attributes or a combination of elements of these. In the schools sector, research by Kuhlthau (2004), Todd (2006), Gordon (2000), Herring (2004 and 2006), Herring and Hurst (2006), Wolfe (2007) and Farmer (2005) has identified a number of areas of interest to teachers and teacher librarians and these include: the affective aspects of information literacy; the use of guided inquiry; the use and evaluation of information literacy models; social-emotional behaviour; concept mapping; and transfer. There are a number of areas of information literacy which teachers and teacher librarians may view as problematic and these include whether students transfer information literacy skills within their school experiences and whether there is any evidence that students transfer information literacy skills from school to higher education or the workplace. The connection between information literacy in schools and lifelong learning may also be questioned as not all students will progress to information related jobs once they leave school. Thus a review of the literature of information literacy in schools can lead teachers and teacher librarians not only to learn more about information literacy concepts, competencies and practices but also to question the validity of some of what is proposed in the literature.

\section{Methodology}

The author takes an interpretivist and constructivist approach to this research. The methods used to collect data were the completion of a structured diary by students and a semi-structured interview with the class teacher. The use of student diaries or journals have been used in previous information literacy research by authors such as Tallman (1998), Harada (2002) and Barranoik (2001). The student diaries are viewed as constructions by the students of their own reality and not verbatim accounts of what they did or thought. Semistructured interviews are viewed as sources of rich data by Burns (2000) and others. The data was analysed using constructivist grounded analysis. Grounded analysis emanates from work on grounded theory which was developed initially by Glaser and Strauss (1967), then by Strauss and Corbin (1998) and constructivist grounded theory was developed by Charmaz (2006) and others. Grounded analysis seeks to answer the question "What is happening?" from the data analysed. As this is an initial phase of a larger study, there is no attempt to develop a grounded theory from the evidence. Constructivist grounded analysis (Charmaz 2006) views the researcher not as an objective, independent viewer of the observed world but, as in this study, as an interpreter of the views of the studied participants. Thus the analysis of the student diaries and the teacher interview allows the researcher to interpret the data with an emphasis on what emerges from the data, as opposed to interpreting the data from the basis of a preconceived standpoint. 


\section{Findings}

The findings, based on the analysis of the student diaries and the teacher interview, were organized into 5 categories:

$>$ Making links

$>$ Being confident

Using information literacy skills and techniques

Students' awareness of their information environment

$>$ Being reflective

These categories were then used to identify the information literacy attributes of this group of students.

The categories were formed from a bringing together of a number of codes which were attached during analysis of the students' diaries. There is overlap between the categories which are not meant to be seen as completely separate and this will be demonstrated graphically in the full paper.

The 'making links' category focuses on students' ability to identify links or connections between different aspects of the information literacy and assignment processes. The 'being confident' category examines students' reflections on how they felt at certain stages of the assignment process and the extent to which their use of information sources and the ideas and information within these sources, made them more or less confident. The 'using information literacy skills and techniques' category analyses how students made use of these skills and techniques to identify relevant information, to evaluate information and ideas within sources and how they reflected on their use of these skills, techniques and sources. The 'students' awareness of their information environment' category examines the extent to which students were aware of the extent and variety of their information environment including their use of print and digital resources, their use of others as information sources and their use of self-created information resources. The 'being reflective' category examines the extent to which students can reflect on their own use of information literacy skills and techniques as well as their own evaluation of their performance in writing the essay.

\section{Conclusion}

There is still a vital need for research into aspects of information literacy amongst school students and this author recommends that this research could usefully seek the views of students at different levels within the school. Interviewing students at different levels and then interviewing the same students later in their school career, would to the knowledge of teachers and teacher librarians who are faced with the enormous task of developing information literate students.

Note: A fuller version of this paper will be sent to School Libraries Worldwide for consideration as a refereed publication. The author's university no longer recognises conference proceedings as refereed publications. 


\section{References}

Barranoik, L 2004, 'Students and their research: architects of meaning', SCAN, vol. 23, no. 2, pp. 33-37.

Burns, R 2000, Introduction to research methods. 4th edition, Frenchs Forest, New South Wales.

Charmaz, K 2006, Constructing grounded theory: a practical guide through qualitative analysis. London, Sage.

Farmer, L 2005, 'Social-emotional behavior and information literacy', in S. Lee, P. Warning, D. Singh, E.

Howe, L. Farmer and S. Hughes (Eds.) IASL Reports 2005: Information leadership in a culture of change. Erie,

PA: International Association of School Librarianship.

Glaser, B and Strauss, A 1967, The discovery of grounded theory: strategies for qualitative research. Chicago, Aldine.

Gordon, C 2000, 'The effects of concept mapping on the searching behavior of tenth-grade students', School Library Media Research, vol. 2, article 6, viewed $15 \quad$ December 2007 , <http://www.ala.org/ala/aasl/aaslpubsandjournals/slmrb/slmrcontents/volume32000/mapping.htm>.

Harada, V 2002, 'Personalising the information search process: a case study of journal writing with elementaryage students', School library Media Research, vol. 5, article 1, viewed 15 December 2007,

$<$ http://www.ala.org/ala/aasl/aaslpubsandjournals/slmrb/slmrcontents/volume52002/slmrvolume52002.htm>.

Herring, J 2004, The internet and information skills: a guide for teachers and school librarians, Facet Publishing, London.

Herring, J 2006, 'A critical investigation of students' and teachers' views of the use of information literacy skills in school assignments’ School Library Media Research, vol. 9. Viewed 15 December 2007,

$<$ http://www.ala.org/ala/aasl/aaslpubsandjournals/slmrb/slmrcontents/volume9/informationliteracy.cfm>

Herring, J and Hurst, J 2006, 'An investigation into the extent to which Year 6 students transfer information literacy across subjects' in McGregor, J and Hay, L eds Research in Teacher Librarianship: Proceedings of the Centre for Studies in Teacher Librarianship Research Conference, Australian National University, Canberra, 910 April 2005. Viewed 15 December 2007,

$<$ http://www.csu.edu.au/faculty/educat/sis/CIS/epubs/CSTLpapers.htm>

Kuhlthau, C 2004, Seeking meaning: a process approach to library and information services. $2^{\text {nd }}$ ed., Libraries Unlimited, Westport CT.

Strauss, A and Corbin, J 1998, Basics of qualitative research. $2^{\text {nd }}$ edn, London, Sage.

Todd, R 2007, 'Guided inquiry supporting information literacy', Scan, vol. 26, no. 28-29. 
Wolf, S 2007, 'Information literacy and self-regulation: A convergence of disciplines', School Library Media Research, vol. 10, viewed 15 December 2007,

$<$ http://www.ala.org/ala/aas1/aaslpubsandjournals/slmrb/slmrcontents/volume10/wolf_informationliteracy.cfm>

\section{Statement of Originality}

This statement certifies that the paper above is based upon original research undertaken by the author and that the paper was conceived and written by the author(s) alone and has not been published elsewhere. All information and ideas from others is referenced. 